\title{
PEMBELAJARAN MATEMATIKA MENGGUNAKAN ALAT PERAGA KEPADA ORANG TUA MURID DALAM RANGKA MEMBANTU MENYELESAIKAN PEKERJAAN RUMAH.
}

\author{
Yosefin Rianita Hadiyanti'), Dewi Kristika Findia Ning Tyas ${ }^{2)}$ \\ 1,2 Program Studi Pendidikan Matematika, FKIP, Universitas Cenderawasih \\ Email: yosefinhadiyanti9578@gmail.com ${ }^{1)}$, dewi.findianingtyas@fkip.uncen.ac.id ${ }^{2)}$
}

\begin{abstract}
Abstrak
pembelajaran matematika menggunakan alat peraga kepada orang tua murid dalam rangka membantu menyelesaikan pekerjaan rumah dilakukan berdasarkan hasil observasi di lapangan ditemui sebagian besar orang tua mengalami kendala dalam membantu anak menyelesaikan PR dikarenakan pengetahuan, dan materi pelajaran anak yang semakin kompleks setelah diberlakukannnya kurikulum 13. Dalam kurikulum 13 anak dituntut aktif, kreatif dan inovatif dalam berbagai hal sehingga peran orang tua sangat penting dalam mendampingi anak mengerjakan PR. Mata pelajaran yang dianggap sulit bagi orang tua adalah matematika. Adapun materi yang diambil yaitu perkalian, pembagian, dan akar pangkat tiga. Strategi yang dilakukan agar membantu orang tua memahami konsep matematika yang memiliki objek kajian yang abstrak dengan menggunakan alat peraga camplung dan lingkaran kubik. Teknik yang digunakan dalam penyampaian melalui ceramah, diskusi dan demonstrasi alat peraga. Adapun langkahlangkahnya: 1) menyampaikan materi prasyarat, 2) menyampaikan materi menggunakan alat peraga, selama penyampaian memberikan kesempatan kepada orang tua untuk bertanya, 3) Orang tua menggunakan alat peraga dalam menyelesaikan soal, 4) memberikan angket balikan untuk melihat keberhasilan kegiatan yang dilakukan. Adapun hasil angket diperoleh: 1) semua orang tua memahami materi yang disampaikan, 2) dapat menggunakan alat peraga, 3) kegiatan yang diberikan memberikan manfaat bagi orang tua dalam mendampingi anak mengerjakan PR.
\end{abstract}

Kata kunci: alat peraga, camplung, lingkaran kubik

\section{PENDAHULUAN}

Mengikuti perkembangan zaman,
pendidikanpun
melakukan perubahan diantaranya melalui perubahan kurikulum. Saat ini kurikulum yang berlaku adalah kurikulum 2013. Salah satu keunggulan dari kurikulum 2013 yaitu mendorong siswa untuk lebih aktif karena kurikulum 2013 didesain secara khusus agar siswa lebih inovatif dan kreatif di dalam berbagai hal. Namun, hal tersebut tanpa disadari menjadi beban tersendiri bagi orang tua siswa. Secara tidak langsung orang tua harus ikut berpartisipasi terutama ketika anak mendapat pekerjaan rumah (PR) atau belajar di rumah. Sebagai orang tua yang harus mendampingi anak untuk belajar/mengerjakan PR di rumah harus mempunyai dasar/bekal sehingga dapat membantu anak dalam belajar/mengerjakan PR. Jika kita hitung jumlah waktu anak lebih banyak di rumah dibandingkan waktunya di sekolah, sehingga peran orang tua sangat penting dalam pendidikan anak. Bisa dibayangkan jika orang tua tidak memahami konsep dasar suatu materi tertentu.

Salah satu mata pelajaran yang membutuhkan pemahaman konsep dan menjadi mata pelajaran yang dianggap susah oleh anakanak adalah mata pelajaran matematika. Matematika pada jenjang Sekolah Dasar (SD) memegang peranan penting sebagai dasar untuk jenjang selanjutnya. Matematika sendiri memiliki objek yang abstrak. Menurut Soejadi (2001) keabstrakan matematika karena objek dasarnya abstrak, yaitu fakta, konsep, prinsip, dan operasi. Sedangkan menurut Santrock (2001) siswa sekolah dasar yang umurnya berkisar antara 6 atau 7 tahun sampai 12 tahun, berada pada operasi konkret yang cenderung berpikir konkret, rasional dan objektif dalam 
memahami suatu situasi. Bisa dibayakan jika pada saat anak-anak mengalami kesulitan mengerjakan PR matematika kemudian orang tua salah/tidak tahu maka akan menyesatkan pemahaman anak. Contohnya pada materi perkalian dan pembagian, anak mendapat PR $4 \mathrm{x}$ $3=\ldots+\ldots+\ldots+\ldots=\ldots$. Soal tersebut sangat sederhana, namun jika orang tua tidak tau konsep dasar perkalian yang merupakan penjumlahan berulang bisa berbahaya. Orang tua tau hasil dari $4 \times 3=12$, namun tidak banyak orang tua yang tau bahwa $4 \times 3=3+3+3+3$. Kemudian untuk pembagian 15:5 = ..- ..- . $=\ldots$ untuk pembagian konsepnya adalah pengurangan berulang. Kasus lainnya misalkan anak mendapat PR menentukan $\sqrt[3]{614.125}=\cdots$ , orang tua dapat menentukan hasilnya dengan menggunakan kalkulator, sedangkan saat ujian anak-anak tidak diijinkan untuk menggunakan kalkulator, sehingga orang tua harus tahu bagaimana menentukan akar pangkat tiga bilangan dengan nilai besar tanpa kalkulator.

Salah satu strategi yang dapat dilakukan agar dapat membantu orang tua siswa memahami konsep matematika yang memiliki objek kajian yang abstrak sehingga dapat membantu anaknya mengerjakan PR adalah dengan menggunakan alat peraga. Menurut Joko Iswadji (dalam Pujiati, 2004) alat peraga matematika adalah seperangkat benda kongkret yang dirancang, dibuat, dihimpun atau disusun secara sengaja yang digunakan untuk membantu menanamkan atau mengembangkan prinsipprinsip dalam matematika. Ruseffendi (1992) menyatakan bahwa alat peraga adalah alat untuk menerangkan atau mewujudkan konsep matematika. Telah banyak penelitian yang menunjukkan bahwa peran alat peraga dapat membantu dalam memahami konsep matematika yang abstrak. Dengan alat peraga, akan lebih mudah memahami konsep yang dipelajari, karena pembelajaran melibatkan aktivitas fisik dan mental, dengan kegiatan melihat, meraba dan memanipulasi alat peraga. Penggunaan alat peraga yang tepat dapat mengoptimalkan fungsi panca indra dan memingkinkan terwujudnya kebermaknaan dalam pembelajaran.

Orang tua yang menjadi sasaran kegiatan pengabdian adalah orang tua siswa SDN Inpres 1 Arso 1 dengan alasan: 1) berdasarkan hasil wawancara dengan paguyupan kelas bahwa orang tua mengalami kesulitan saat membantu anak-anak mengerjakan PR, 2) SDN Inpres 1 merupakan sekolah induk yang tertua di wilayah Arso, 3) jumlah siswa paling banyak se wilayah Arso, 4) belum pernah menerima kegiatan pelatihan alat peraga. Berdasarkan uraian di atas maka akan dilakukan pengabdian dengan judul "Pembelajaran Matematika Menggunakan Alat Peraga kepada Orang Tua Murid dalam Rangka Membantu Menyelesaikan Pekerjaan Rumah".

\section{METODE PELAKSANAAN Mitra Kegiatan Pengabdian Kepada Masyarakat}

Kegiatan Pengabdian Kepada Masyarakat ini dilakukan kepada orang tua murid SDN Inpres 1 Arso 1 dengan pertimbangan 1) berdasarkan hasil wawancara dengan paguyupan kelas bahwa orang tua mengalami kesulitan saat membantu anak-anak mengerjakan PR, 2) SDN Inpres 1 merupakan sekolah induk yang tertua di wilayah Arso, 3) jumlah siswa paling banyak se wilayah Arso, 4) belum pernah menerima kegiatan pelatihan alat peraga.

\section{Bahan dan alat Peraga Kegiatan Pengabdian Kepada Masyarakat \\ Cangplung}

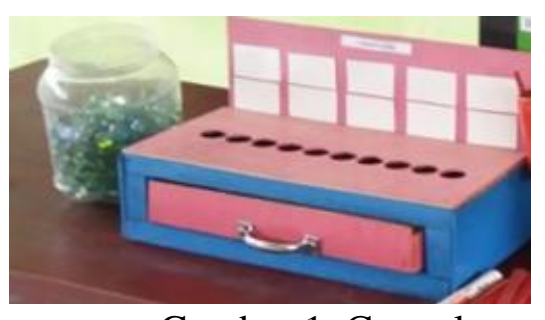

Gambar 1. Cangplung

- Alat dan Bahan 
- Alat : palu, paku, meteran, pensil, gergaji dan spidol

Bahan : tripleks, kayu, lem, cat, white board, kelereng, pegangan laci.

- Cara membuat :

- Siapkan alat dan bahan.

- Buat rangka dari kayu dengan ukuran panjang $50 \mathrm{~cm}$, lebar $20 \mathrm{~cm}$ sebanyak 2 buah (untuk atas dan bawah).

- Potong tripleks dengan panjang $50 \mathrm{~cm}$ dan lebar $20 \mathrm{~cm}$ sebanyak 2 buah dan potong tripleks lagi dengan ukuran panjang $20 \mathrm{~cm}$ dan lebar $15 \mathrm{~cm}$ sebanyak 2 buah.

- Tempelkan tripleks yang sudah dipotong-potong pada rangka yang sudah dibuat tadi sehingga membentuk balok.

- Kemudian buat 10 lubang pada permukaan tripleks bagian atas balok.

- Buat laci pada balok tersebut dan pasang pegangan laci agar mudah membuka laci.

- Buatlah latar. Potong tripleks dengan panjang $50 \mathrm{~cm}$ dan lebar $35 \mathrm{~cm}$ kemudian tempel pada bagian belakang balok.

- Siapkan white board dan potong sebanyak 10 buah susuai ukuran.

- Susun mendatar pada latar.

- Beri cat pada seluruh permukaan tripleks agar terlihat menarik.

Lingkaran Kubik

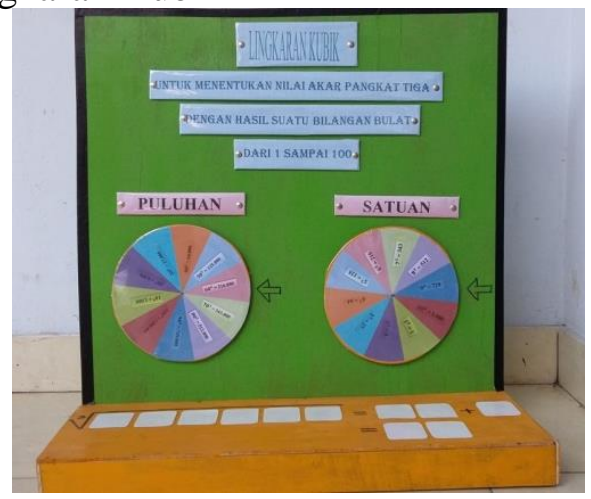

Gambar 2. Lingkaran Kubik

- Alat dan Bahan
Alat : Gergaji, Meteran, Gunting, Pisau cutter, Kuas, Palu, Printer, Spidol

Bahan : Tripleks, Paku tripleks, Paku tindis, Cat, Lakban, Lem, Plastic bening,

Kertas HVS, Kertas, whiteboard

- Cara Membuat

Papan landasan

- Potong tripleks dengan ukuran $61 \mathrm{~cm} \mathrm{x}$ $61 \mathrm{~cm}$ untuk landasan papan.

- Potong 2 tripleks lainnya dengan ukuran $5 \mathrm{~cm}$ x $20 \mathrm{~cm}$ sebagai kaki penyangga bagian samping dan 2 tripleks lainnya lagi dengan ukuran $5 \mathrm{~cm}$ x $61 \mathrm{~cm}$ sebagai kaki penyangga bagian depan

- Potong tripleks tipis dengan bentuk lingkaran berdiameter $21 \mathrm{~cm}$.

- Potong tripleks tebal dengan ukuran 61 $\mathrm{cm}$ x $21 \mathrm{~cm}$ sebagai alas papan landasan.

- Dengan menggunakan paku tripleks, tripleks-tripleks yang telah dipotong disusun dan direkatkan satu sama lain sedemikian rupa sehingga terbentuk seperti yang diinginkan kemudian dilakukan pengecetan untuk membuat alat peraga terlihat semakin menarik.

Tulisan

- Potong papan tripleks yang ukurannya tipis dengan ukuran $17 \mathrm{~cm} \mathrm{x} 6 \mathrm{~cm}, 41 \mathrm{~cm}$ x $5 \mathrm{~cm}, 34 \mathrm{~cm} \times 5 \mathrm{~cm}, 18 \mathrm{~cm} \times 5 \mathrm{~cm}$, dan ukuran $18 \mathrm{~cm}$ x $3 \mathrm{~cm}$.

- Cetak tulisan-tulisan yang akan ditempelkan pada alat peraga dengan menggunakan kertas HVS berwarna biru dan merah muda.

- Tempelkan kertas judul yang sudah dicetak pada tripleks yang sudah di potong tersebut dan melapisinya dengan plastik bening.

- Pasang judul alat peraga yang telah dibuat pada papan lingkaran dengan menempelkannya menggunakan paku tindis.

- Cetak tulisan-tulisan bilangan kubik yang berbentuk lingkaran pada kertas HVS. 
- Tempelkan kertas tersebut pada papan lingkaran kemudian melapisinya dengan plastik bening.

- Pasang lingkaran kubik yang terdiri dari puluhan dan satuan pada papan lingkaran tersebut dengan menggunakan paku tripleks dengan posisi di bawah judul alat peraga.

\section{Bagian-Bagian Alat Peraga Lingkaran Kubik}

Papan Landasan

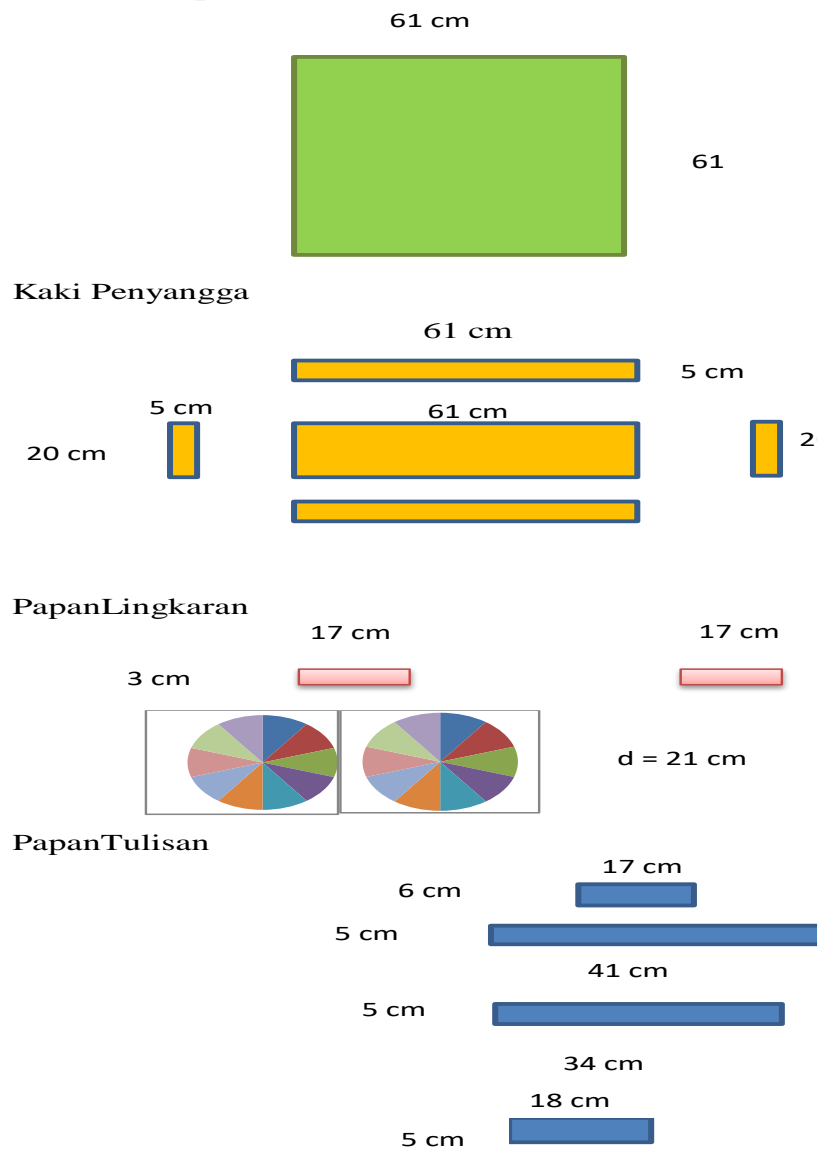

Penggunaan alat peraga Kegiatan

Pengabdian Kepada Masyarakat

Cangplung

- Cara penggunaan

Contoh perkalian:

- Siapkan spidol dan kelereng

- Kemudian susun/tulis angka pada white board yang sudah tertempel di latar sesuai dengan pertanyaan yang diajukan sehingga membentuk penjumlahan berulang.
- Misalkan contoh pertanyaan adalah $2 \times 3$ $=3+3$ maka tulis angka pada white board pertama angka 3 dan pada white board kedua angka 3 juga sesuai dengan contoh pertanyaannya.

- Masukkan kelereng kedalam lubang sesuai dengan jumlah angka yang terdapat pada latar.

- Tarik laci untuk mengetahui hasil dari perkalian dengan menghitung jumlah kelereng yang telah dimasukkan tadi.

Contoh pembagian :

- Siapkan spidol dan kelereng.

- Misalkan contoh pertanyaannya $6: 2=$. . . $>6-2-2-2=0$ maka ambil kelereng sebanyak 6 buah, dan masukkan 2 buah kelereng ke dalam lubang pertama, 2 buah kelereng lagi kedalam lubang kedua, dan 2 buah kelereng pada lubang ketiga. Sampai semua kelereng yang sudah diambil habis.

- Beri tanda centang pada white board setelah memasukkan kelereng pada setiap lubang.

- Hitung banyaknya centang pada white board untuk mengetahui hasil dari pembagian.

\section{Lingkaran Kubik}

Cara Menggunakan Alat Peraga

Perhatikan pasangan-pasangan bilangan asli dalam "lingkaran kubik"

- Untuk menentukan hasil akar pangkat tiga dari bilangan kubik satuan, puluhan, dan ratusan cukup melihat lingkaran satuan pada alat peraga. Hasil akar pangkat tiga dari bilangan kubik tersebut adalah angka yang dipangkatkan tiga yang sama dengan bilangan kubik tersebut.

Contoh:

- $\sqrt[3]{8}=\ldots$

8 adalah bilangan kubik satuan. Pada "lingkaran satuan", angka 8 menunjuk pada $2^{3}$. Maka: $\sqrt[3]{8}=2$

- $\sqrt[3]{64}=\ldots$ 
64 adalah bilangan kubik puluhan. Pada "lingkaran satuan", angka 64 menunjuk pada $4^{3}$. Maka: $\sqrt[3]{64}=4$

- $\quad \sqrt[3]{512}=\ldots$

512 adalah bilangan kubik ratusan. Pada "lingkaran satuan", angka 512 menunjuk pada $8^{3}$. Maka: $\sqrt[3]{512}=8$

- Untuk bilangan kubik lebih dari ratusan, kita harus memperhatikan pasangan-pasangan bilangan pada lingkaran puluhan dan lingkaran satuan pada "lingkaran kubik".

- Perhatikan bilangan kubik yang diberikan.

- Abaikan tiga angka dari belakang pada bilangan kubik tersebut. Perhatikan angka yang tersisa dengan memperhatikan nilai tempat. Posisikan angka yang tersisa diantara dua bilangan kubik pada lingkaran puluhan. Ambil bilangan kubik yang lebih kecil dan lihat pasangannya. Kemudian tuliskan hasilnya pada tempat yang disediakan.

- Perhatikan angka satuan pada bilangan kubik. Cari angka satuan bilangan kubik pada lingkaran satuan yang sama dengan angka satuan bilangan kubik yang akan dihitung hasilnya. Pasangan dari angka satuan tersebut merupakan angka satuan dari hasil akar pangkat tiga bilangan kubik yang diberikan.

Contoh:

- $\sqrt[3]{3.375}=\ldots$

- Abaikan tiga angka dari belakang maka angka yang tersisa dibaca 3.000. Perhatikan lingkaran puluhan. Angka 3.000 terletak pada bilangan kubik 1.000 dan 8.000. Pilih angka yang lebih kecil yaitu 1.000. Angka 1.000 menunjuk pada $10^{3}$ maka tuliskan angka 10 pada tempat yang disediakan,

- Angka satuan dari 3.375 adalah 5. Perhatikan bilangan kubik pada lingkaran satuan. Bilangan kubik yang satuannya juga adalah 5 yaitu 125 . Angka 125 menunjuk pada $5^{3}$ maka tuliskan angka 5 pada tempat yang disediakan.
- Hitung $10+5=15$

Maka hasil dari $\sqrt[3]{3375}=15$.

- $\sqrt[3]{24.389}=\ldots$

- Abaikan tiga angka dari belakang maka angka yang tersisa dibaca 24.000. Perhatikan lingkaran puluhan. Angka 24.000 terletak pada bilangan kubik 8.000 dan 27.000. Pilih angka yang lebih kecil yaitu 8.000. Angka 8.000 menunjuk pada $20^{3}$ maka tuliskan angka 20 pada tempat yang disediakan,

- Angka satuan dari 24.389 adalah 9. Perhatikan bilangan kubik pada lingkaran satuan. Bilangan kubik yang satuannya juga adalah 9 yaitu 729 . Angka 729 menunjuk pada $9^{3}$ maka tuliskan angka 9 pada tempat yang disediakan.

- $\quad$ Hitung $20+9=29$

$$
\text { Maka hasil dari } \sqrt[3]{24.389}=29
$$

\section{Pengumpulan dan interpretasi Data}

Untuk melihat apakah peserta dapat menggunakan alat peraga dan memahami materi yang diberikan, peserta diminta mengisi angket, jika $75 \%$ peserta dapat menggunakan alat peraga dan memahami materi yang diberikan maka kegiatan pengabdian kepada masyarakat dianggap berhasil.

\section{HASIL DAN PEMBAHASAN Hasil Kegiatan Pengabdian Kepada Masyarakat}

Kegiatan Pengabdian Kepada Masyarakat ini dilakukan kepada orang tua murid SDN Inpres 1 Arso 1. Dalam melakukan pembelajaran alat peraga dan tulis disiapkan.

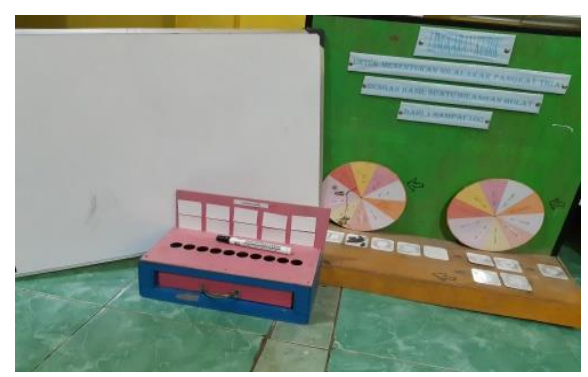


whiteboard

Gambar 3. alat peraga, spidol dan

Materi pertama yang disampaikan adalah perkalian dengan menggunakan alat peraga camplung. Dalam mempelajari materi perkalian harus menguasai materi penjumlahnan, untuk itu pamteri sebelumnya memastikan apakah semua orang tua memahami materi penjumlahan. Semua orang tua memahami materi penjumlahan. Sebelum menggunakan alat peraga camplung, pemateri bertanya " $2 \times 3=$. . .", semua orang tua menjawab $2 \times 3=6$. Pemateri selanjutnya bertanya arti dari " $2 \times 3=2+2+2$ atau $2 \times 3=3+3$ ?", sebanyak 14 orang yang menjawab salah. Pemateri kemudian menjelaskan materi perkalian dan memberikan contoh dengan menggunakan camplung. Selama menyampaikan materi dan memperagakan alat peraga pemateri meberikan kesempatan kepada orang tua untuk bertanya. Semua orang tua tau hasil perkalian, namun tidak memahami konsep perkalian, dimana perkalian merupakan penjumlahan berulang. Setelah orang tua memahami penggunakan alat peraga camplung, pemateri memberikan soal, dimana orang tua mengerjakannnya dengan menggunakan alat peraga. Semua orang tua dapat menggunakan alat peraga camplung dan menjawab soal dengan benar.

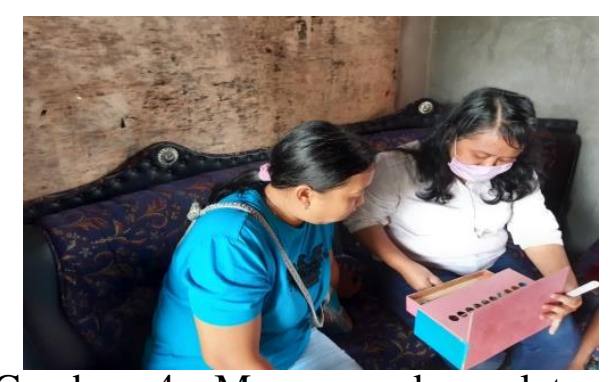
camplung

Gambar 4. Memperagakan alat peraga

Materi kedua yang disampaikan adalah pembagian, masih dengan alat peraga yang sama yaitu camplung. Pemateri memastikan semua orang tua memahami materi pengurangan. Semua orang tua memahami materi pengurangan, selanjutnya pemateri menyampaikan materi pembagian dengan menggunakan alat peraga camplung. Selama penyampaian materi dan memperagakan alat peraga pemateri memberikan kesempatan kepada orang tua untuk bertanya. Untuk menmastikan apakah orang tua memahami amteri dan dapat menggunakan alat peraga camplung, pemateri meminta orang tua mengerjakan soal dengan menggunakan alat peraga camplung. Semua orang tua sudah memahami konsep pembagian, dimana pembagian adalah pengurangan berulang dan dapat menggunakan camplung dalam menjawab soal pemabgian yang diberikan.

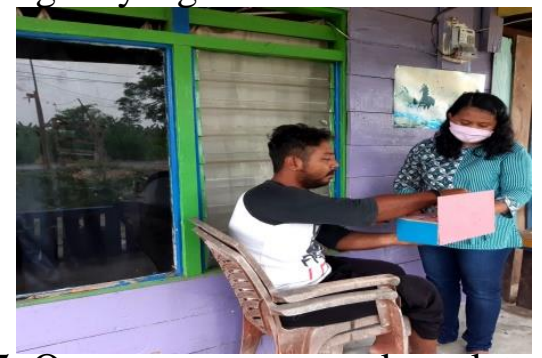

Gambar 5. Orang tua menggunakan alat peraga

Materi terakhir yang disampaikan adalah akar pangkat tiga dari suatu bilangan. Untuk dapat menguasai materi akar pangkat tiga dari suatu bilangan, orang tua harus memahami materi perkalian dan bilangan berpangkat tiga. Semua orang tua memahami materi perkalian yang sudah dijelaskan sebelumnya dan bialangn berpangkat tiga. Pemateri bertanya kepada orang “ $\sqrt[3]{8}=$. . .", semua orang tua menjawab benar. Selanjutnya pemateri bertanya $" \sqrt[3]{27000}=\ldots$. " sebagian bersar orang tua menjawab benar. Pemateri melanjutkan pertanyaan selanjutnya “ $\sqrt[3]{1728}=\ldots$. . , semua orang tua tidak bisa menjawab. Beberapa orang tua mengatakan untuk menjawab akar pangkat tiga dari suatu bilangan yang besar mereka menggunakan kalkulator. Pemaeri kemudian memperkenalkan alat peraga lingkaran kubik, dan menjelaskan bagaimana cara penggunakaannya. Kemudian memberikan beberapa contoh soal akar pangkat tiga dari suatu bilangan yang besar dengan menggunakan alat peraga lingkaran kubik. Selama menjelaskan dan memperagakan alat peraga lingkaran kubik, pemateri memberikan kesempatan kepada orang tua untuk bertanya. Setelah oraang tua memahami, pemateri memberikan kesempatan kepada orang tua untuk 
menggunakan alat peraga lingkaran kubik dalam mengerjakan soal yang diberikan.
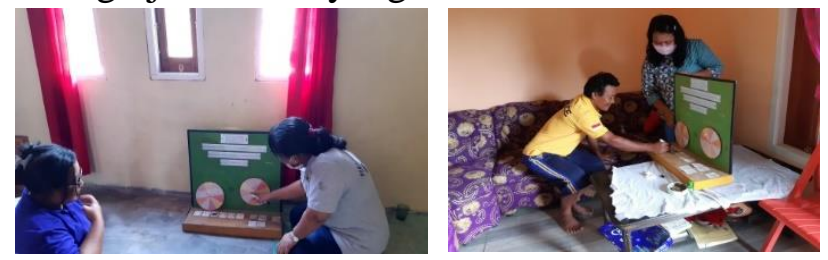

Gambar 6. Mempraktekkan alat peraga lingkaran kubik

Diakhir pertemuan, pemateri mengingatkan kembali materi dan penggunaan alat peraga yang telah disampaikan. Kemudian, memberikan kesempatan kepada orang tua untuk bentanya. Tidak ada oaring tua yang bertanya diakhir kegiatan.

Untuk mengukur apakah orang tua memahami dan dapat menggunakan alat peraga yang telah dijelaskan, pemateri memberikan angket balikan untuk diisi semua orang tua yang telah menerima materi. Hasil angket menunjukkan semua orang tua memahami materi yang disampaikan, dapat menggunakan alat peraga camplung dan lingkar kubik serta kegiatan yang diberikan memberikan manfaat dalam rangka membantu menyelesaikan PR anak.

\section{Pembahasan Kegiatan Pengabdian Kepada Masyarakat}

Pembelajaran matematika menggunakan alat peraga kepada orang tua murid dalam rangka membantu menyelesaikan pekerjaan rumah diawali dengan menyampaikan materi prasyarat, hal tersebut dilakukan agar orang tua mudah memahami materi yang disampaikan nantinya, hal ini sesuai dengan hasil penelitian Anita, P. P., Nursalam, \& Sri, S., (2014) bahwa terdapat pengaruh antara penguasaan materi prasyarat terhadap hasil belajar matematika.

Semua orang tua memahami materi prasyarat, selanjutnya adalah menyampaikan materi dengan menggunakan alat peraga. Strategi tersebut dilakukan agar dapat membantu orang tua siswa memahami konsep matematika yang memiliki objek kajian yang abstrak, hal tersebut senada dengan Ruseffendi (1992) menyatakan bahwa alat peraga adalah alat untuk menerangkan atau mewujudkan konsep matematika.

Dalam menyampaikan materi dengan menggunakan alat peraga, orang tua diberikan kesempatan untuk bertanya. Semua orang tua mengikutinya dengan baik, terlihat dari keseriusan dalam memperhatikan penjelasan, aktif bertanya, dan dapat menggunakan alat peraga. Hal tersebut diperkuat dengan hasil angket balikan yang diisi semua orang tua setelah mengikuti kegiatan. Hasil angket menunjukkan semua orang tua memahami materi yang disampaikan, dapat menggunakan alat peraga camplung dan lingkar kubik serta Kegiatan yang diberikan memberikan manfaat dalam rangka membantu menyelesaikan PR anak.

\section{Dampak Kegiatan Pengabdian Kepada Masyarakat}

Dampak dari diadakannya kegiatan pengabdian kepada masyarakat yaitu 1) semua orang tua memahami materi yang disampaikan, 2) dapat menggunakan alat peraga, 3) kegiatan yang diberikan memberikan manfaat bagi orang tua dalam mendampingi anak mengerjakan PR.

\section{SIMPULAN}

Pembelajaran Matematika Menggunakan Alat Peraga kepada Orang Tua Murid dalam Rangka Membantu Menyelesaikan Pekerjaan Rumah langkah-langkahnya 1) menyampaikan materi prasyarat, 2) menyampaikan materi menggunakan alat peraga, selama penyampaian memberikan kesempatan kepada orang tua untuk bertanya, 3) Orang tua menggunakan alat peraga dalam menyelesaikan soal, 4) memberikan angket balikan untuk melihat keberhasilan kegiatan yang dilakukan. Adapun hasil angket diperoleh: 1) semua orang tua memahami materi yang disampaikan, 2) dapat menggunakan alat peraga, 3) kegiatan yang diberikan memberikan manfaat bagi orang tua dalam mendampingi anak mengerjakan PR.

\section{DAFTAR PUSTAKA}


Anita, P. P., Nursalam, \& Sri, S. (2014). Pengaruh Penguasaan Materi Prasyarat Terhadap Hasil Belajar Matematika Siswa Kelas VIII SMPN 1 Sinjai Timur. Jurnal Matematika dan Pembelajarannya.

Asma, N. 2005. Stretegi Belajar Mengajar Matematika. Jakarta: Pustekkom.

Djamarah, S. B, Zain, A. 2006. Strategi Belajar Mengajar. Jakarta : Rineka Cipta.

Hamalik, O. 2001. Proses Belajar Mengajar. Jakarta : Bumi Aksara.

Pujiati. 2004. Penggunaan Alat Peraga dalam Pembelajaran Matematika SMP.Yokyakarta: Direktorat Pendidikan Dasar dan Menengah

Ruseffendi, E.T. 1992. Pendidikan Matematika 3.Jakarta:Departemen Pendidikan dan Kebudayaan Proyek Pembinaan Tenaga Kependidikan Pendidikan Tinggi.

Santrock, J. W. 2007. Perkembangan Anak. Jakarta : Erlangga

Sri Subarinah. 2006. Inovasi Pembelajaran Matematika Sekolah Dasar. Jakarta: Depdiknas

Sundayana, H. 2015. Media Dan Alat Peraga Dalam pembelajaran Matematika. Jakarta: Alfabeta 